\title{
A new stream and nested catchment framework for Australia
}

\author{
J. L. Stein, M. F. Hutchinson, and J. A. Stein \\ Fenner School of Environment and Society, Australian National University, Canberra, ACT, Australia \\ Correspondence to: J. L. Stein (janet.stein@ anu.edu.au)
}

Received: 25 October 2013 - Published in Hydrol. Earth Syst. Sci. Discuss.: 17 December 2013

Revised: 27 March 2014 - Accepted: 28 March 2014 - Published: 22 May 2014

\begin{abstract}
Nationally framed assessment and planning assists coordination of resource management activities across jurisdictional boundaries and provides context for assessing the cumulative effects of impacts that can be underestimated by local or regional studies. However, there have been significant shortcomings in the existing spatial frameworks supporting national assessment and planning for Australia's rivers and streams.

We describe the development of a new national stream and nested catchment framework for Australia that includes a fully connected and directed stream network and a nested catchment hierarchy derived using a modified Pfafstetter scheme. The directed stream network with associated catchment boundaries and Pfafstetter coding respect all distributary junctions and topographically driven surface flow pathways, including those in the areas of low relief and internal drainage that make up over half of the Australian continent. The Pfafstetter coding facilitates multi-scale analyses and easy tracing and query of upstream/downstream attributes and tributary/main stem relationships. Accompanying the spatial layers are 13 lookup tables containing nearly 400 attributes describing the natural and anthropogenic environment of each of the $1.4 \mathrm{M}$ stream segments at multiple spatial scales (segment, sub-catchment and catchment).

The database supplies key spatial layers to support national water information and accounting needs and assists a wide range of research, planning and assessment tasks at regional and continental scales. These include the delineation of reporting units for the Australian Water Resources Assessment, the development of an ecohydrological environment classification for Australian streams and the identification of high conservation value aquatic ecosystems for northern Australia.
\end{abstract}

\section{Introduction}

A continental framework for natural resource planning and assessment enables management activities to be coordinated across jurisdictional boundaries (Corkum, 1999; Jensen et al., 2001). Continental assessment also provides unambiguous evidence of the cumulative impact of human activities (Boulton and Brock, 1999; Ormerod, 1999; Frissell et al., 2001) that are often underestimated by local or regional studies (Hughes et al., 2000; Australian State of the Environment Committee, 2001). This is especially important for crossborder rivers and streams where local decision-making can undermine the broader goals of environmentally sustainable management (Kingsford et al., 1998, 2005; Australian State of the Environment Committee, 2001). A national framework can guide priority setting for national funding programs and provide context for more detailed and specifically targeted planning and assessment (Veitch and Walker, 2001).

However, the continental frameworks that have been available for planning and assessment of Australia's water resources have significant shortcomings. The most widely adopted of these, the Australian Water Resources Council (AWRC) River Basins and Drainage Divisions (Fig. 1) (Australian Water Resources Council, 1976; AUSLIG, 1997; Geoscience Australia, 2003a) has served for several decades, but does not always adhere to topographically defined hydrological boundaries and does not recognise the distributaries that link many major river systems. The Murray River, for example, divides river basins within the MurrayDarling Basin Drainage Division, while the boundary between the Paroo and Warrego River basins intersects a distributary that connects the two (Kingsford et al., 2001). The AWRC river basins confuse a number of spatial scales and are too coarse for many water resource assessment needs. They include topographically defined basins (e.g. the Fitzroy 


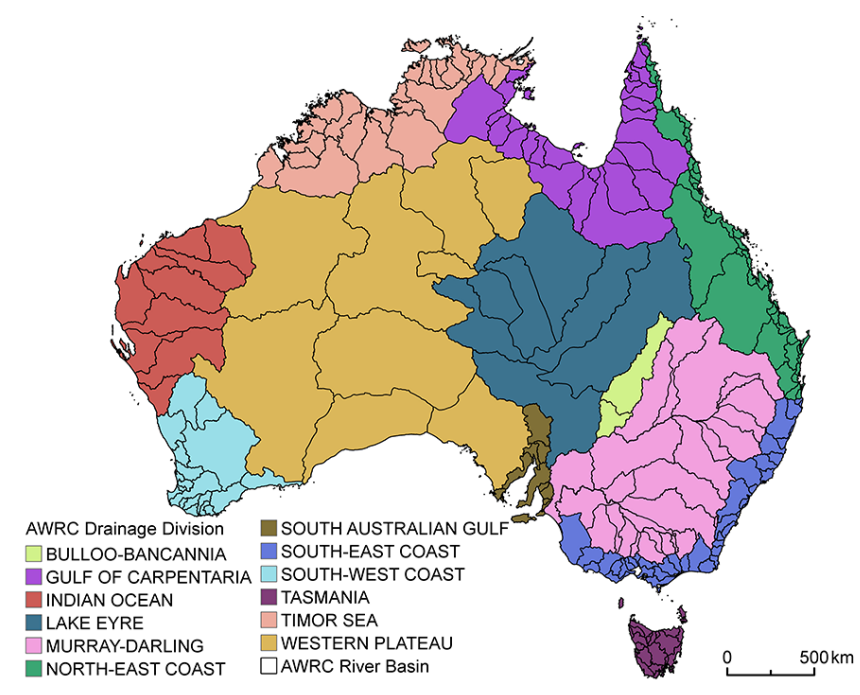

Figure 1. Australian Water Resource Council (AWRC) Drainage Divisions and River Basins.

River in Queensland), the catchments of major rivers (e.g. in the Murray-Darling Basin) and sub-catchments (e.g. the lower Avon River in Western Australia). The nested subcatchments that supported the National Land and Water Resources Audit (Hutchinson et al., 2000) supplied a finer subdivision of topographically derived catchments. However, these catchments also fail to recognise distributary drainage structures, and the patterns of drainage density, derived by application of uniform area thresholds, are inconsistent with observed patterns, especially in areas with low topographic relief or extreme aridity. These areas make up over half of the Australian continent (Hutchinson et al., 2008).

A national catchment framework requires an underpinning spatially consistent streamline network. However, the streams comprising the 1:250000 scale Geodata TOPO $250 \mathrm{~K}$ series 3 watercourse lines (Geoscience Australia, 2006), the most accurately located national stream layer, were not consistently directed downstream. The more recently published Australian Hydrological Geospatial Fabric (AHGF) cartographic streams (Bureau of Meteorology, 2010), based largely on the Geodata TOPO 250K series 1 watercourse lines (AUSLIG, 1992), are consistently directed but display major disparities in drainage density across map sheet boundaries. Both are cartographic products that are not readily amenable to spatial analysis tasks such as catchment delineation and network tracing.

Global drainage data sets also have serious shortcomings as national frameworks for planning and assessment. The earlier of these were developed from digital elevation models (DEMs) at relatively coarse spatial scales of $30^{\prime}$ to $1^{\circ}$ to provide a basis for continental and global scale modelling of water and sediment transport (Renssen and Knoop, 2000; Vörösmarty et al., 2000; Döll and Lehner, 2002). The HYDRO1k data set (US Geological Survey, 2001) includes streams, drainage basins and ancillary layers (e.g. slope, aspect, contributing area) derived from the USGS' 30 s DEM of the world (GTOPO30). HYDRO1k delivers a nested hierarchical catchment framework by successively sub-dividing drainage basins according to the Pfafstetter scheme (Verdin and Verdin, 1999). The most recent, and the most accurate of the global hydrological databases, known as HydroSHEDS (Lehner et al., 2008, http://www.hydrosheds.org/), supplied a river network and a basin layer for Australia at $15 \mathrm{~s}$ grid cell resolution. These global data sets, however, map only the larger streams. Thus the contributing area thresholds applied to delineate the HydroSHEDS and HYDRO1K stream networks exclude streams with contributing areas less than 20 and $1000 \mathrm{~km}^{2}$, respectively. HydroSHEDS also offers a seamless flow direction grid at $3 \mathrm{~s}$ resolution to enable users to apply a lower contributing area threshold and thus delineate smaller streams. However, it is difficult to identify suitable thresholds to represent the highly variable drainage density that occurs across the Australian continent. Importantly, none of the global databases recognise distributary and anabranching drainage structures.

Here we introduce a new national stream and nested catchment framework for Australia that overcomes many of these limitations. We begin with an overview of our approach, and the encoding of surface flow pathways in the $9 \mathrm{~s}$ DEM (Hutchinson et al., 2008) on which it depends. This is followed by a description of the framework components and their development. Applications of the new framework across a range of disciplinary areas, as well as limitations of the framework, are also described. The paper concludes by comparing key aspects of the new framework with other catchment databases and discussing future developments.

\section{Drainage analysis methods}

The spatial framework that underpins the National Stream and Catchment database has been developed using new methods of drainage analysis of a DEM that are especially suited to application at continental scale. In particular, these methods recognise the extensive distributary drainage structures and natural variability in drainage density that occur across the Australian continent. They significantly extend those presented in earlier material (Stein, 2006; Stein et al., 2009a) and will be described fully in a forthcoming manuscript. Analyses were undertaken using raster-based methods both for reasons of computational efficiency and for compatibility with the raster DEM on which many of the attributes characterising the land surface depend. However, for ease of display and mapping, each of the spatial layers in the database is also supplied in vector format by converting the raster outputs.

All components of the database fundamentally depend on the surface flow pathways encoded in the national $9 \mathrm{~s}$ flow direction grid as calculated in 43 rectangular tiles by version 5.2 of the ANUDEM program (Hutchinson et al., 2008; 
Hutchinson, 2011). This version includes a multiple-flow extension that incorporates flow to an anabranch at each distributary point in the stream network. Infrequent shortcomings in the grid, including loops at tile edges, spurious sinks, spurious multiple flow directions, flow directions that produced catchment "tails" or crossing flow paths, and flow pathways that connected from the mainland to close islands (in an adjacent grid cell), were corrected using a combination of automatic procedures and manual editing. Supplementary flow directions were also added to a grid cell where the two directions coded by ANUDEM were insufficient to ensure the connectivity of flow pathways in the more complex braided or anastomosed sections of the channel network. More recently, these procedures have been fully automated so that the task of removing such anomalies in the flow direction grid is more easily replicated. Improvements in the ANUDEM elevation gridding program have also reduced the number of such anomalies and hence reduced the need for corrections to the flow direction grid.

\section{A nested stream and catchment framework}

The new framework includes three closely linked components (Fig. 2):

1. a fully connected and directed stream network that recognises distributary drainage structures, derived from the national $9 \mathrm{~s}$ DEM and flow direction grid version 3 (Hutchinson et al., 2008)

2. a nested hierarchy of catchments and associated Pfafstetter coding that respects these distributary junctions

3. readily interrogated lookup tables that provide attributes describing the natural and anthropogenic characteristics of the stream and catchment environment.

\subsection{DEM stream network}

The stream network was derived by tracing the flow pathways encoded in the multiple flow direction grid from the gridded channel heads of the AusHydro cartographic streams (the foundation layer for the AHGF mapped streams) to an outlet on the coast or an inland sink. The distributary points encoded into the flow direction grid ensure that the derived network connects streams and their anabranches.

Unlike the more commonly adopted method based on the application of a constant contributing area threshold (Montgomery and Foufoula-Georgiou, 1993; Hutchinson et al., 2000; Jenson, 1991; Verdin and Verdin, 1999), this method delineates a continent-wide steam network with a variable drainage density that is consistent with the mapping scale of the streamlines used to support the construction of the DEM, which in this case is about $1: 250000$. The resolution of the DEM, however, limits the extent of the stream network and

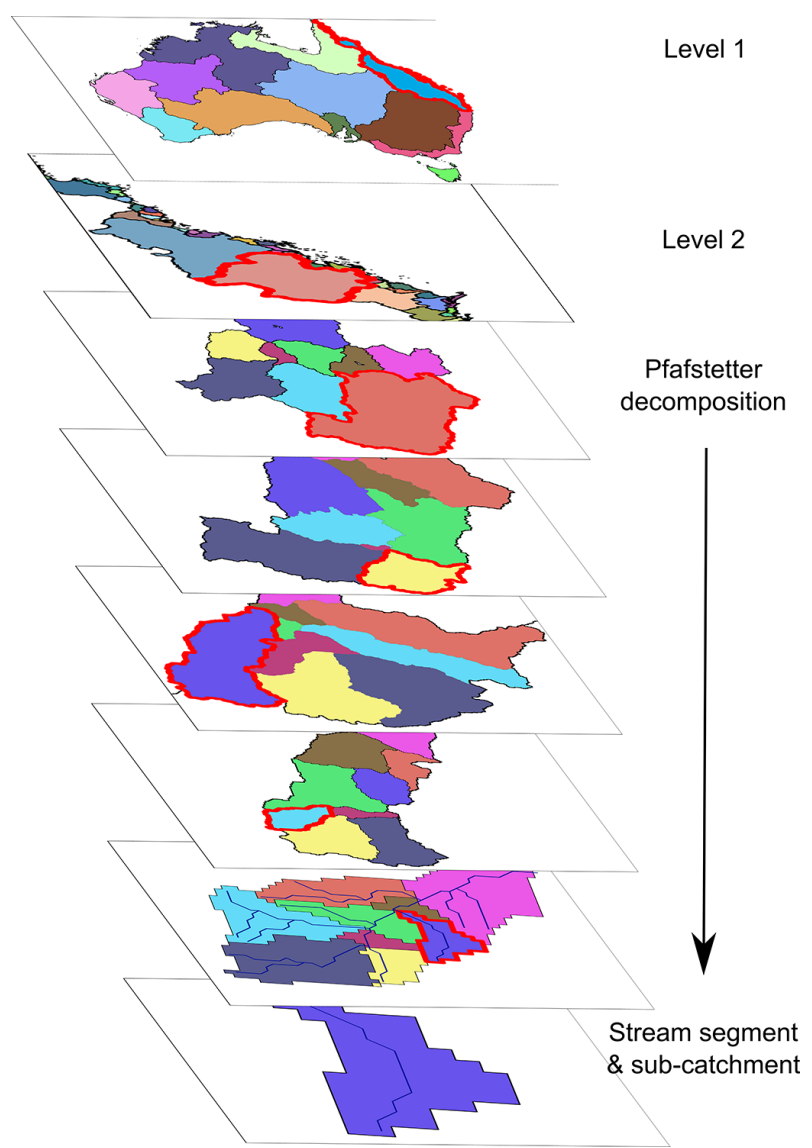

Figure 2. Components of the nested stream and catchment database. The nested hierarchy of catchments aggregates drainage basins at its highest levels and at its lower levels, sub-divides basins into successively smaller catchment units based on the Pfafstetter system. The smallest units in the catchment framework are the catchment areas draining to individual stream segments in the associated DEM stream network. Attributes describing the natural and anthropogenic environment of the stream and its catchment are contained in the related lookup tables. The area shown at each level is highlighted with a red boundary at the next higher level.

the size of the drainage features that can be extracted (Garbrecht and Martz, 1994). Thus, source channels with a contributing area of less than $1.25 \mathrm{~km}^{2}$ at their pour point were removed, while main stem segments draining larger upstream contributing areas were retained to their source.

The raster stream network was divided into uniquely identified segments by inserting breaks at all tributary confluences and distributary points, where a channel flows into or out of an AusHydro water body or over a cliff, and where the traced network connects gaps in the AusHydro watercourse lines (a "DEM connector") (Fig. 3).

An AusHydro identifier was assigned to each segment to link it to the corresponding AusHydro watercourse line feature based on their shared topological relationships. The attributes associated with the AusHydro cartographic streams 


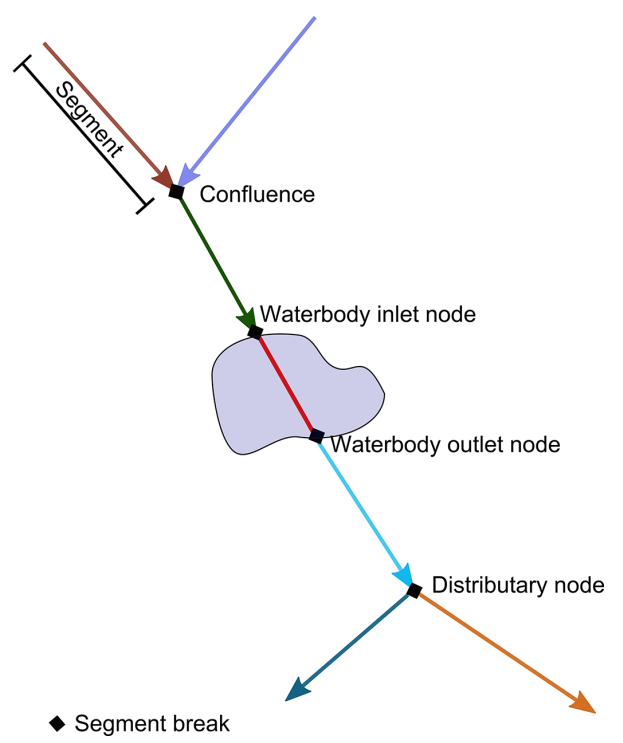

Figure 3. Breaks inserted into the DEM stream network at confluences, distributary nodes and water bodies. The breaks delineate uniquely identified stream segments.

(stream name, hierarchy and perenniality) were then transferred to the corresponding DEM stream segment. Occasional shortcomings in the attribution, such as missing names or an inconsistent hierarchy assignment, were corrected using automatic procedures to trace the network to ensure that attribution followed expected downstream conventions. Thus, it was assumed that major hierarchy status was maintained along the main channel to the stream network outlet. Similarly, attribution was traced downstream to the DEM connectors that were not associated with a cartographic stream.

The derived stream network comprises nearly $1.4 \mathrm{M}$ stream segments and has a total length of $3.3 \mathrm{M} \mathrm{km}$. About $90 \%$ of these segments are bounded by tributary confluences or distributary points. The remainder comprise 122578 DEM connectors that join gaps in the mapped stream network, just over 64000 water body connectors (of which $89 \%$ are located within a natural lake and $11 \%$ within a reservoir) and 2700 segments that break the stream at a cliff.

Segments vary in length from that of a single grid cell (about $270 \mathrm{~m}$ ) up to $243 \mathrm{~km}$, with an average segment length of $2.4 \mathrm{~km}$. This variation reflects the natural variability in drainage density across the continent, as mapped at a scale of $1: 250000$, without the discrepancies between map tiles due to differences in cartographic interpretation.

The locations of the streams derived from the DEM accurately reflect the locations of the input map streams. A random sample of 1000 points along the DEM stream lines (excluding DEM connectors) on each of the 44 tiles that correspond to Geoscience Australia's 1:1 million scale map series were found to be on average $61 \mathrm{~m}$ from an AusHydro watercourse, the expected difference due to gridding and generalisation of the vector stream lines to the grid cell resolution of $9 \mathrm{~s}$ of latitude and longitude. Just $5 \%$ of the sample points were located more than $125 \mathrm{~m}$ from an AusHydro watercourse and all were less than $500 \mathrm{~m}$ away.

\subsection{Hierarchically nested catchments}

The nested hierarchy of catchments (Fig. 2) was formed by first aggregating, then successively sub-dividing, drainage basins using a modified version of the Pfafstetter scheme of Verdin and Verdin (1999). The Pfafstetter scheme labels each catchment unit with a code that conveys useful information about stream topological characteristics and higher-level relationships. It stands out among other methods for delineating and coding catchment units for its efficient use of digits, its ease of implementation, the ready interpretation of its coding scheme and its widespread use (Stein and Hutchinson, 2008).

The Pfafstetter scheme uses the topology of the stream network and the size of the drainage area to guide the subdivision of drainage basins into successively smaller catchment units that are coded with the digits 0 to 9 sequentially from the outlet of the catchment unit upstream to its source. Thus, the four largest tributary catchments are coded with the even digits 2 to 8 while the five inter-catchment units are assigned the odd digits between 1 and 9 . A single closed (internal draining) basin, being the largest in area within the larger, higher-level catchment unit, is assigned a Pfafstetter code of 0 .

\subsubsection{Drainage basins}

Drainage basins delineate the entire connected drainage areas of each outlet to the sea and each inland sink such as a natural depression or lake. The same identifier was assigned to drainage areas that were connected by a distributary, or drained to multiple sinks within a single lake so that these connected areas were together recognised as a single drainage basin. For example, the Norman, Staaten, Gilbert and Flinders rivers, draining to the Gulf of Carpentaria, are linked by distributaries and their drainage areas delineate a single basin (Fig. 4). Small drainage basins flowing to a connected group of grid cells in the sea but not drained by a DEM stream were similarly aggregated and treated as a single drainage basin.

Nearly 90000 (88434) drainage basins were thus delineated, each basin draining to one or more outlets on the coast ( $44 \%$ by area) or to inland sinks ( $56 \%$ by area) (Fig. 5). However, only 722 basins have an area greater than $1000 \mathrm{~km}^{2}$. More than $80 \%$ of the basins are very small (less than $10 \mathrm{~km}^{2}$ ). These include the areas draining to clusters of clay pans or small dry lakes inland or directly to the sea rather than through a river mouth on the coastal fringe. Just 49 of the basins with an area less than $10 \mathrm{~km}^{2}$ are drained by a named AusHydro stream. In contrast, the 


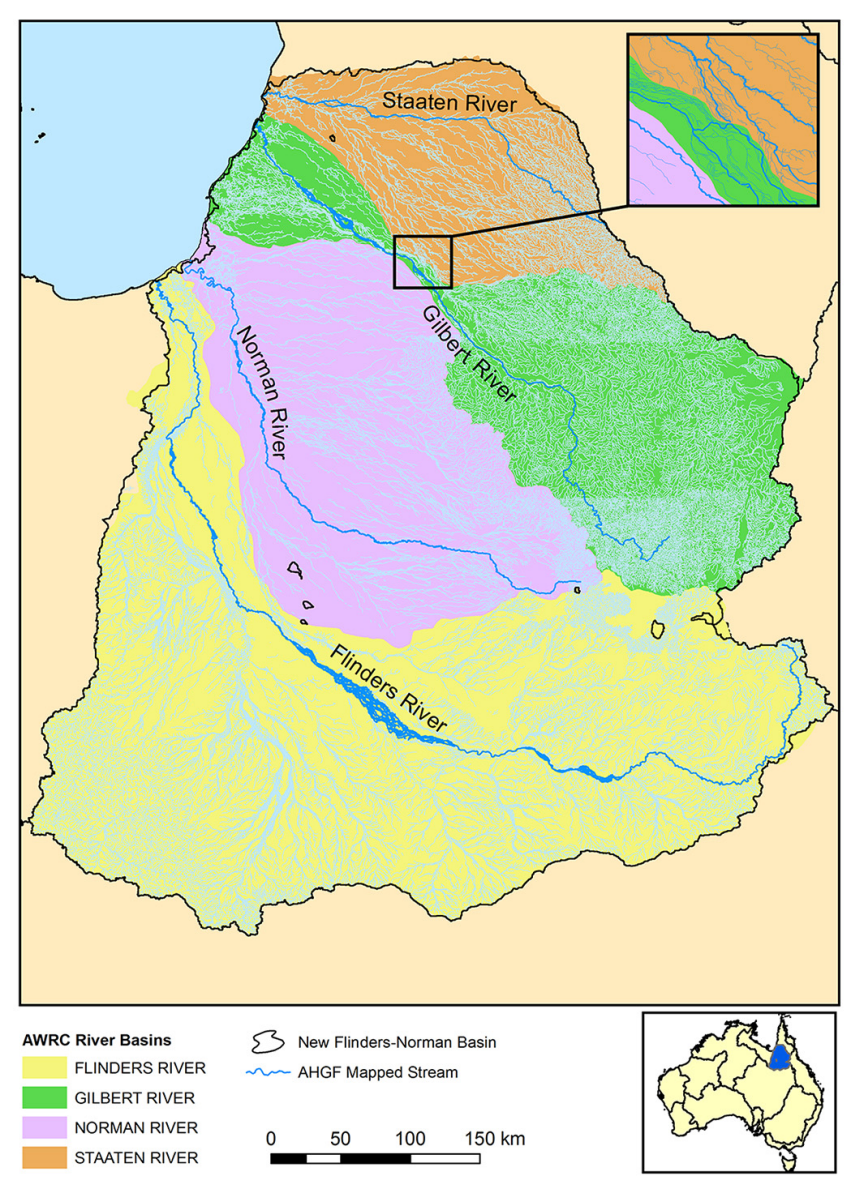

Figure 4. The Flinders-Norman Drainage Basin combining the catchment areas of the Norman, Flinders, Staaten and Gilbert rivers that are linked by floodplain distributaries. In contrast, the AWRC river basins delineate four separate river basins with boundaries drawn through the floodplain distributary channels. Note also the small areas of internal drainage.

largest basins are typically drained by a major river system or terminate in a large lake (Table 1). The new drainage analysis recognises substantial areas of internal drainage within the Murray-Darling Basin. Consequently, the total area draining to the mouth of the Murray River is calculated to be nearly $270000 \mathrm{~km}^{2}$ less than the usually quoted area of $1059000 \mathrm{~km}^{2}$ (http://www.mdba.gov.au/about-basin/ basin-environment/georgraphy/geology-and-size).

\subsubsection{Level 1 and 2: aggregated drainage basins}

Levels 1 and 2 of the nested catchment framework were derived by grouping the drainage basins based largely on the AWRC boundaries. This produced more evenly sized regions than the Pfafstetter scheme when applied at the continental level (Stein, 2006). Linking with the AWRC boundaries also facilitates the transfer of existing water resource information to the new framework.

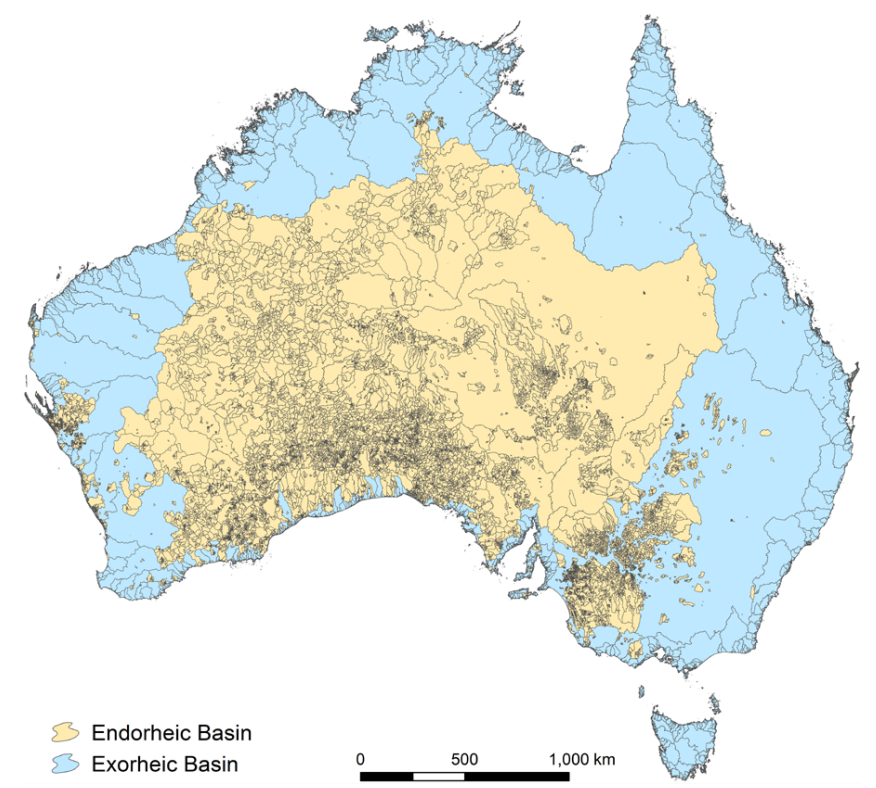

Figure 5. Drainage basins delineated from the $9 \mathrm{~s}$ DEM.

The Level 1 topographic drainage divisions (Fig. 6) were thus delineated by first allocating each of the coastal-draining basins to the AWRC drainage division that occupied the majority of the drainage basin area. Internally draining basins were then associated with either a coastal draining AWRC division or the interior Lake Eyre drainage basin by successively merging them with a lower neighbouring drainage basin via the lowest pour point on the basin divide. The derived Level 1 boundaries were compared with the AWRC boundaries, the topographically based analysis by Hutchinson and Dowling (1991), palaeodrainage systems established by van de Graaff (1977) and colleagues and divisions similarly derived from locally averaged $1 \mathrm{~s}$ Shuttle Radar Topography Mission (SRTM) data (Gallant et al., 2011). Major discrepancies were further checked by local inspection of the terrain features on Landsat imagery (Furby, 2002) and $1: 100000$ topographic mapping.

Supported by the additional evidence, we reassigned the group of internally draining basins draining towards Lake Breaden in the Gibson Desert in Western Australia from the North Western Plateau division to the South Western Plateau division. For compatibility with the legislated administrative boundaries for the Murray-Darling Basin (MDB) that are based on the old AWRC boundaries, the Level 1 boundaries were also modified to move a small group of internally draining basins along the MDB southern border from the MDB division to the Level 1 South-east Coast division. In both cases, the elevations of the competing pour points on the drainage divide differed by less than the $10 \mathrm{~m}$ standard elevation error of the 9 s DEM (Hutchinson et al., 2008). 
Table 1. Australia's largest drainage basins with area $>25000 \mathrm{~km}^{2}$.

\begin{tabular}{lr}
\hline Basin name & Area $\left(\mathrm{km}^{2}\right)$ \\
\hline Lake Eyre (North) & 826161 \\
Murray-Darling Basin & 792600 \\
Flinders-Norman rivers & 231314 \\
Fitzroy River (Qld) & 141283 \\
Burdekin River & 129868 \\
Gascoyne River & 103688 \\
Fitzroy River (WA) & 91190 \\
Victoria River & 89416 \\
Ord River & 83800 \\
Nicholson-Leichhardt rivers & 82947 \\
Mitchell River (Qld) & 82743 \\
Swan River & 81790 \\
Ashburton River & 74975 \\
Bulloo River & 70915 \\
Roper River & 66445 \\
Murchison River & 65368 \\
De Grey River & 59431 \\
Lake Moore & 55538 \\
Lake Frome & 51366 \\
Lake Gregory & 49496 \\
Daly River & 49443 \\
Fortescue River & 48671 \\
Hanson River & 48580 \\
Lake Mackay & 38164 \\
Burnett River & 33272 \\
Lake Torrens & 32020 \\
Hay River & 30621 \\
Lake Disappointment & 30382 \\
Newcastle Waters/Lake Woods & 28844 \\
\hline
\end{tabular}

Level 2 in the catchment hierarchy was delineated by subdividing the Level 1 drainage basin groupings based on the AWRC river basins (Fig. 6). Thus, the $9 \mathrm{~s}$ topographically defined drainage basins were associated with an AWRC river basin draining to the sea or in the case of the internally draining Lake Eyre Drainage Division, into Lake Eyre (North). The associated AWRC river basin was the one that occupied the majority of the $9 \mathrm{~s}$ drainage basin area or, if an internally draining $9 \mathrm{~s}$ basin, the AWRC river basin that it would be associated with if the $9 \mathrm{~s}$ basin were to overflow successively into lower neighbouring basins via the lowest pour points.

\subsubsection{Level 3 and beyond: application of a modified Pfafstetter scheme}

The Level 2 basin groups were sub-divided into successively smaller basin and sub-basin units using a modified version of the Pfafstetter scheme of Verdin and Verdin (1999). The continental-scale Pfafstetter scheme of Verdin and Verdin was applied to initially divide and code Level 2 basin groups. The Verdin system was then modified to successively subdivide these drainage basins into tributary catchments and

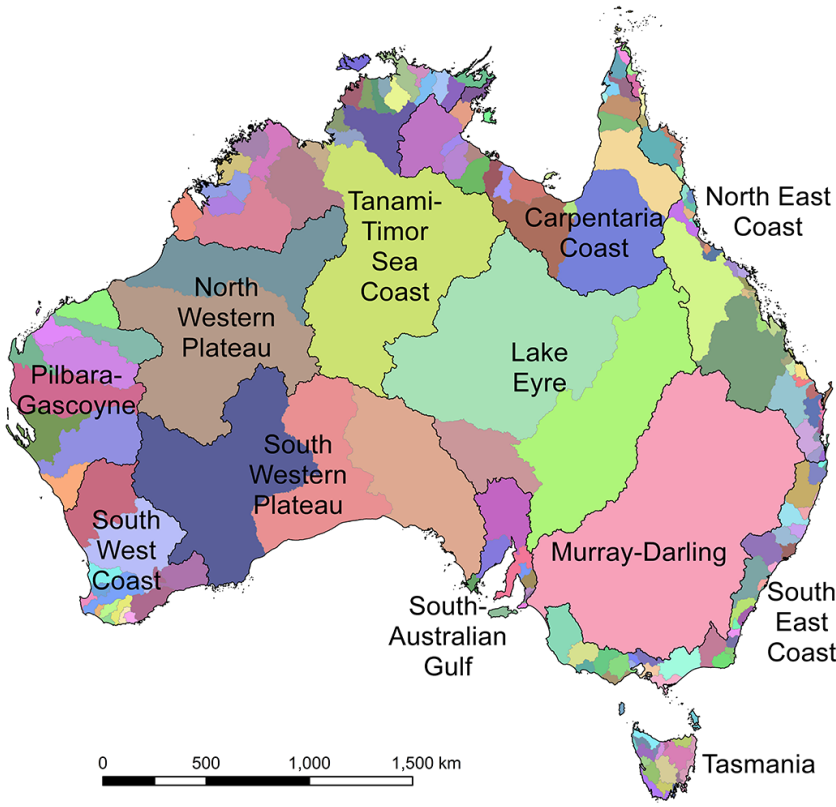

Figure 6. Levels 1 and 2 of the new hierarchically nested catchment framework. Shown are the Level 1 topographic drainage division names.

main stem "inter-basins", using a modelled estimate of annual mean runoff volume rather than contributing area to discriminate the tributary and main stem. Runoff volume was calculated by summing the upstream values of the annual time series of runoff estimates produced by the Australian Water Availability Project for the years 1900 to 2007 (Raupach et al., 2009; 2012). The Pfafstetter system was also extended to include a coding method for distributary and anabranching drainage systems and catchments that drained stream networks with less than four tributaries.

Only distributary channels that drained to an alternative outlet or into a different tributary basin were coded separately from the main stem. Other multi-channel streams were assigned a Pfafstetter code as if a single channel. The identifier of the upstream main stem segment (in the case of an anabranch) or the downstream anabranch segment (if a main stem segment that is an anabranch off-take) and the level in the catchment hierarchy at which the anabranch is coded separately from the main stem channel are recorded in the database. This allows the user to optionally include these relationships in network tracing and catchment delineation tasks.

The original Verdin and Verdin scheme codes only the largest of the internally draining basins at each level. This was modified so that a Pfafstetter code was assigned to each of the numerous internally draining basins that were delineated from the $9 \mathrm{~s}$ DEM. Each of these smaller, internally draining basins was assigned the Pfafstetter code of the catchment unit to which it would flow if it were to overflow into the lower neighbouring basin via the lowest pour point 
Table 2. Number and average area of catchment units at each level in the nested hierarchy.

\begin{tabular}{lrr}
\hline Level & $\begin{array}{r}\text { Number of } \\
\text { catchment units }\end{array}$ & $\begin{array}{r}\text { Average } \\
\text { area }\left(\mathrm{km}^{2}\right)\end{array}$ \\
\hline 1 & 12 & 641977 \\
2 & 191 & 40334 \\
3 & 1740 & 4427 \\
4 & 12614 & 611 \\
5 & 56782 & 136 \\
6 & 161198 & 47.8 \\
7 & 336753 & 22.9 \\
8 & 559250 & 13.8 \\
9 & 748118 & 10.3 \\
10 & 881719 & 8.7 \\
11 & 978391 & 7.9 \\
12 & 1036084 & 7.4 \\
13 & 1066063 & 7.2 \\
14 & 1082029 & 7.1 \\
15 & 1090035 & 7.1 \\
\hline
\end{tabular}

on the drainage divide, a process akin to that used to associate the internally draining basins with a Level 1 or 2 unit.

A 13-level Pfafstetter sub-division of the Level 2 basin aggregations was derived to obtain a 15 -level nested catchment hierarchy overall. The finest level sub-division in the nested hierarchy delineates the sub-catchment areas draining to each of the segments in the DEM stream network or, where there were no AusHydro watercourse features, the drainage basins that drain directly to the coast or an inland sink. The size of the catchment units varies greatly within each level of the hierarchy, depending on the extent of drainage basin subdivision, although the average area of the catchment units changes little after Level 9 (Table 2).

The hierarchical relationships of the catchments are coded into the catchment identifier that combines the Level 1 drainage division and Level 2 basin group together with the 13-level Pfafstetter code. Not all basins were sub-divided as far as the topology of the stream network allowed, even after 15 levels of sub-division. For instance, small, internally draining basins are so numerous in some areas that many still needed to be merged with a lower neighbour for Pfafstetter code assignment, as they were not yet the largest internal basin. To assist users wishing to utilise the Pfafstetter coding within a specific basin, the database also records the results of an independent, 15-level, within-basin Pfafstetter sub-division applied to each drainage basin individually to code every tributary and main stem stream segment in the basin.

\subsection{Stream and catchment environmental descriptors}

An extensive suite of environmental descriptors (Table 3) characterise the natural and anthropogenic environment of each stream segment and its catchment at three, increasingly broader, spatial scales:

1. the local stream and its valley as defined by the grid cells that comprise the stream segment and where appropriate, the adjacent valley bottom flats;

2. the sub-catchment, being the local area draining directly to a segment in the DEM stream network and the smallest spatial units of the catchment hierarchy; and

3. the entire catchment upstream or, for some attributes, the flow path downstream of the sub-catchment outlet cell.

The stream valley was delineated by the valley bottom flats identified from the values of the multi-resolution Valley Bottom Flatness (mrVBF) and Ridge Top Flatness (mrRTF) indices calculated using the method of Gallant and Dowling (2003) for the 9 s DEM.

The selection of attributes for inclusion was informed by literature review (Stein, 2006) and the requirements of national- and regional-scale applications (Walsh et al., 2007; Stein et al., 2009b; Kennard, 2010), constrained by the availability of data with consistent continent-wide coverage. The principal objective was to include attributes that described key drivers of stream ecological, hydrological and geomorphological processes.

Catchment mean values were calculated by averaging the values of all grid cells upstream of the stream segment outlet cell, dividing accumulated totals and cell counts at bifurcations in the stream network in the ratio of 8 rivers: 4 creeks : 1 unnamed streams: 0.1 floodplain wetlands, based on the ratios observed for gauged streams (Stein, 2006). Custom tools were developed to calculate the catchment attribute values, as the multiple flow directions used to encode distributary points in the stream network were not recognised by the flow accumulation and routing functions in standard GIS packages. These distributary drainage structures also required special treatment so that, for example, stream order did not increment and contributing areas were not counted twice when bifurcating streams rejoined downstream.

To ensure that small but potentially important features were included, categorical source data (geology, land use and vegetation) were gridded and classified at a grid cell resolution finer than $9 \mathrm{~s}$, and then the proportion of each $9 \mathrm{~s}$ grid cell occupied by each category used to calculate the stream segment, sub-catchment or catchment summary values. Indicators of connectivity were derived by considering the length of stream that was unimpeded by built structures (dam walls, spillways or large reservoirs) that formed potential barriers to in-stream movement of aquatic biota. The location of a stream segment relative to a natural barrier (a waterfall or cliff) was also recorded in the database, as was the name of the AWRC river basin overlaying the majority of the segment sub-catchment to enable linkages with existing data organised according to the AWRC spatial framework. 
Table 3. Stream environment descriptors. Data are organised into lookup tables that can be related to both the DEM streams and catchment spatial layers using a shared segment identifier.

\begin{tabular}{|c|c|c|}
\hline Table & Description & Primary source data \\
\hline Climate & $\begin{array}{l}\text { Parameters describing annual and seasonal climate and } \\
\text { rainfall erosivity }\end{array}$ & $\begin{array}{l}\text { ANUCLIM (Xu and Hutchinson, 2013) } \\
\text { National Land and Water Resources Audit (2000) } \\
\text { 9s DEM version } 3.1 \text { (Hutchinson et al., 2008) }\end{array}$ \\
\hline Terrain & $\begin{array}{l}\text { Elevation, relief, slope, aspect, catchment area and shape, } \\
\text { stream order, confinement, distance from source/outlet }\end{array}$ & 9s DEM version 3.1 (Hutchinson et al., 2008) \\
\hline Substrate & Soil hydrological characteristics and lithological composition & $\begin{array}{l}\text { Surface geology of Australia } 1: 1 \mathrm{M} \text { (Liu et al., 2006; } \\
\text { Raymond et al., 2007a, b, c; Stewart et al., 2008; Whitaker } \\
\text { et al., 2007, 2008), Soil hydrological properties of Aus- } \\
\text { tralia (Western and McKenzie, 2004) }\end{array}$ \\
\hline Veg; Veg-MVSG & $\begin{array}{l}\text { Catchment and valley natural and extant vegetation cover } \\
\text { (forests, woodlands, shrubs, grasses, bare), } \\
\text { Valley natural and extant vegetation cover (NVIS major } \\
\text { vegetation sub-groups) }\end{array}$ & $\begin{array}{l}\text { NVIS } 100 \mathrm{~m} \text { (Australian Government Department of the } \\
\text { Environment and Water Resources, 2006a, b) }\end{array}$ \\
\hline Runoff & $\begin{array}{l}\text { Monthly time series of accumulated runoff volume } 1970 \\
\text { to } 2008 \text {, summary statistics describing annual and sea- } \\
\text { sonal mean and extreme conditions, inter- and intra-annual } \\
\text { variability }\end{array}$ & $\begin{array}{l}\text { Monthly climate surfaces } 1970 \text { to } 2008 \text { (Kesteven et al., } \\
\text { 2004; Hutchinson, 2004) } \\
\text { GROWEST water balance module (Hutchinson et al., } \\
\text { 2004) }\end{array}$ \\
\hline NPP & $\begin{array}{l}\text { Catchment average of annual and monthly mean net primary } \\
\text { productivity }\end{array}$ & Raupach et al. (2001) \\
\hline Land use & $\begin{array}{l}\text { Stream and valley and catchment average and maximum } \\
\text { population density, proportion of stream and valley, sub- } \\
\text { catchment or catchment on which particular land use activ- } \\
\text { ities take place }\end{array}$ & $\begin{array}{l}\text { Catchment-scale land use mapping for Australia (Bureau } \\
\text { of Rural Sciences, 2009), Population density } 2006 \\
\text { (Australian Bureau of Statistics, 2006) }\end{array}$ \\
\hline River disturbance & $\begin{array}{l}\text { Indicators of pressure on stream ecosystems due to human } \\
\text { activities (Stein et al., 2002) }\end{array}$ & $\begin{array}{l}\text { Data sources in Stein et al. (1998) updated with catchment- } \\
\text { scale land use mapping for Australia (Bureau of Rural Sci- } \\
\text { ences, 2009), Geodata TOPO 250K series } 2 \text { (Geoscience } \\
\text { Australia, 2003b), Integrated Vegetation Cover (Bureau of } \\
\text { Rural Sciences, 2003) }\end{array}$ \\
\hline Network & Stream network parameters/indicators of habitat availability & AusHydro (Bureau of Meteorology, 2010) \\
\hline connectivity & $\begin{array}{l}\text { Presence of major in-stream barriers including dams and } \\
\text { waterfalls }\end{array}$ & 9 s DEM Version 3.1 (Hutchinson et al., 2008) \\
\hline Identifiers & $\begin{array}{l}\text { AWRC and topographically defined basin identifier, up and } \\
\text { downstream segment identifiers, outlet geographic location }\end{array}$ & Australia's River Basins (AUSLIG, 1997) \\
\hline
\end{tabular}

The summary statistics derived from the monthly time series of runoff are indicative of the catchment water balance. They were produced by summing the upstream values of the grid cell runoff estimates calculated by the single bucket water balance model of the GROWEST program (Hutchinson et al., 2004). This runoff model was well suited to continentwide application, as it required just two parameters that were set based on grid cell soil attributes. Runoff generated using alternative models are currently being investigated and may be readily substituted.

The stream and catchment environmental descriptors are best explored within a GIS or in the context of particular applications. Nevertheless, it is possible to derive directly from the database useful summaries that can demonstrate the continent-wide spatial variation in key drivers of riverine processes and the human activities that threaten the integrity of those processes (Table 4). Thus, while the variability in runoff in Australia is often highlighted (McMahon et al., 2007), and supported by our modelling, it is also clear that there are many regions that experience less variable runoff and thus more reliable stream flow (Fig. 7).

\section{Discussion}

\subsection{A new national framework}

The new national framework has been developed to support resource assessment and planning for Australia's rivers and streams. It overcomes many of the shortcomings of previously available national catchment data. Its continent-wide delineation of streams and their catchments is based consistently on surface topography, irrespective of administrative arrangements.

The analysis of these catchments has identified previously unrecognised areas of inland drainage, including those within the Murray-Darling Basin. It also highlights the prevalence $(56 \%)$ of endorheic drainage in Australia, in contrast to other continents where endorheic regions occupy less 
Table 4. Characteristics of Australian streams and catchments: examples derived from the environmental descriptors for a subset of named streams.

\begin{abstract}
Longest flow path (source to outlet along main channel)
Wettest stream (highest catchment average annual rainfall)

Driest stream (lowest catchment average annual rainfall)

Hottest stream (highest catchment average maximum

temperature of the hottest month)

Coldest stream (lowest catchment average minimum

temperature of the coldest month)

Greatest relief (basin with highest relief ratio)
\end{abstract}

Least relief (basin with the lowest relief ratio)

\author{
Most variable flow (basin of named stream with highest CV \\ annual mean accumulated runoff, 1970-2008) \\ Basin with greatest proportion of annual mean runoff \\ (1970-2008) generated above the snow line \\ Most urbanised basin
}

Largest undisturbed or minimally disturbed stream $(\mathrm{RDI} \leq 0.01)$

(Stein et al., 2002)

Undisturbed or minimally disturbed stream length $(\mathrm{RDI} \leq 0.01)$

(Stein et al., 2002)

Stream length fragmented by large dams (up or downstream)
Murray-Darling Basin $(3515 \mathrm{~km})$

East Mulgrave River, Queensland (3845 mm)

Manuwalkaninna Creek, Lake Eyre Basin $(110 \mathrm{~mm})$

Dead Horse Creek, Ashburton River Basin $\left(41.4{ }^{\circ} \mathrm{C}\right)$

Swampy Plain River, Murray-Darling Basin $\left(-5.7^{\circ} \mathrm{C}\right)$

Ketchem Creek, southern Tasmania (relief 594 m, basin length $4.8 \mathrm{~km})$

Station Creek, Gulf of Carpentaria, Qld. (relief $6 \mathrm{~m}$, basin length

$25.7 \mathrm{~km})$

Manunda Creek, South Australia (largest of 108 basins with

$\mathrm{CV}=6.2$ )

Mersey River, Tasmania (32\%)

Cherry Creek, Melbourne, Victoria $\left(78.9 \%\right.$ of the $19 \mathrm{~km}^{2}$

catchment is urban land use)

South Alligator River, Northern Territory

$5.95 \%$ length of named streams

$45.6 \%$ length of named streams than $20 \%$ of the landmass and as low as $5 \%$ in North America (Hammer, 1986).

The Level 1 and 2 groupings of drainage basins reveal the broader-scale drainage structure of the continent and indicate some significant departures from the AWRC boundaries, most notably for the Western Plateau Drainage Division and the rivers flowing into the Timor Sea. Consistent with the drainage analysis of Hutchinson and Dowling (1991), and the palaeodrainage analysis of van de Graaff (1977) and others, our analysis recognises a major drainage divide that splits the Western Plateau Division into northern and southern sections associated with drainage into the Indian Ocean and Great Australian Bight, respectively. Also consistent with Hutchinson and Dowling (1991), our analysis links the AWRC basins Mackay, Wiso and Barkly, which were included within the Western Plateau Division, to coastal basins in the AWRC Timor Sea Drainage Division and includes the AWRC Bulloo Bancannia Division within the Lake Eyre Level 1 division.

Unlike the AWRC second tier however, our Level 2 division encompasses entire drainage basins and does not divide the Murray-Darling and Swan River drainage basins. Similarly, by recognising distributary drainage structures, connected drainage areas have been delineated where the AWRC identified separate basins. Our analysis required that internally draining basins, such as the AWRC river basins of Mackay and Warburton, were connected to either the coast or Lake Eyre. Accordingly, our Level 2 analysis delineates 54 fewer aggregated basin units than the 245 AWRC river basins.

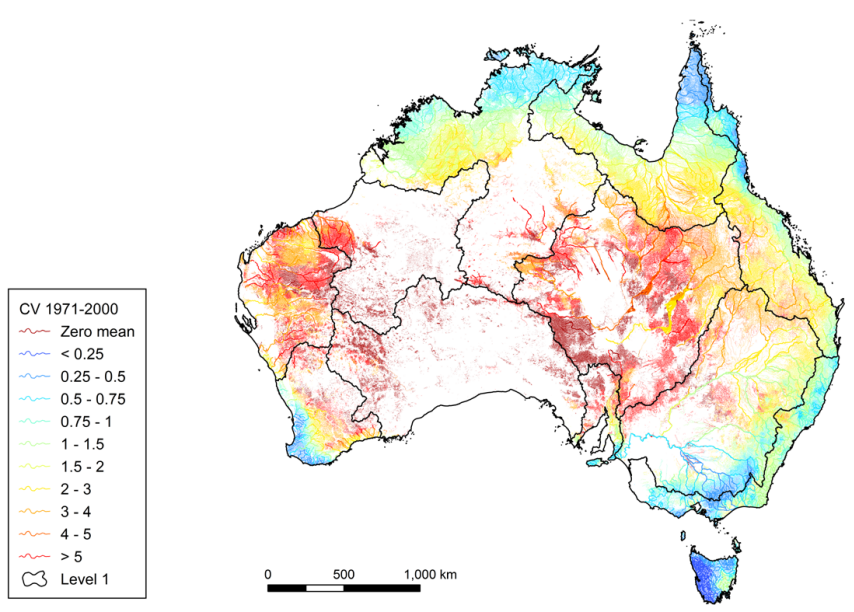

Figure 7. Interannual runoff variability: coefficient of variation of the annual totals of accumulated runoff volume for the period 1971 to 2000. Values extracted from the runoff lookup table described in Sect. 3.3.

The stream network derived from the DEM complements the AHGF cartographic streams. The direct link to subcatchments and the enhanced connectivity of the DEMderived product facilitates network tracing and other analytical tasks while the shared AusHydro identifier enables users to link the results of these analyses to the AHGF cartographic streams. 
The Pfafstetter coding associated with each stream segment and its sub-catchment encodes complex streamline and nested catchment relationships in a readily accessible form. Users are thus able to infer information about topological relationships in a catchment using simple algebraic queries, for example, to identify all sections of a river network upor down-stream of any feature of interest or to discriminate main stem and tributary streams. The identifying codes also enable users to extract catchments at any level in the hierarchy, allowing the scale of analysis and reporting to be varied to match the scale of the available data and to optimise the derived spatial patterns for particular applications. The size of the catchment unit at each level in the nested hierarchy varies substantially, largely as a consequence of the natural variation in drainage density and basin size that occurs at continental scale. Nevertheless, it is relatively straightforward to extract catchment units from different levels for each drainage basin to satisfy requirements for more homogenously sized catchment units.

The Pfafstetter coding and unique catchment identifiers can be associated with other features of the hydrological system located within the sub-catchment, whether natural (e.g. wetlands and lakes) or anthropogenic (stream gauges, locks, weirs, dams). This catchment reference system establishes a standard and seamless scheme for consistent referencing of water features to assist coordinated approaches to cross-agency water resource data collection and collation, overcoming the difficulties associated with current systems based on stream names that are inconsistently applied (e.g. streams that change their name along their length or share the same name) or are simply unnamed (Wilson and Nason, 1991).

We have modified the Pfafstetter scheme of Verdin and Verdin (1999) to use modelled runoff rather than contributing area to discriminate the main stem and tributary. This reduces the likelihood of erroneous main stem assignment for rivers draining the larger, but more arid regions of a drainage basin. However, a change in the model used to derive the runoff estimates, or indeed in the time period over which they were calculated, might require re-assignment of the Pfafstetter codes and hence the delineation of the levels of the nested catchments in some drainage basins.

The database supplies attributes that describe the stream and catchment environment at multiple spatial scales. These attributes characterise important drivers of hydrological, geomorphological and ecological processes that in turn influence water resource availability and condition and ultimately, river ecosystem patterns and processes. For example, the size and shape of the catchment influence the water and sediment yield and its timing and distribution (Fryirs and Brierley, 2012) while measures of slope and relief provide an indicator of the energy available for sediment transport and the potential for erosion or deposition (Jerie et al., 2003).

\subsection{Applications}

The seamless national data offered by the new framework can support a wide range of modelling and analytical uses in addition to more traditional reporting and mapping applications. The data have already been used to

1. assist the selection of monitoring sites for bioassessment programs (Gilligan, 2010; Davies et al., 2010)

2. develop models of reference condition for macroinvertebrate community composition and channel physical form for the Murray-Darling Basin Sustainable Rivers Audit program (Walsh et al., 2007; Davies et al., 2010, 2012)

3. underpin an ecohydrological environment classification for Australia (Pusey et al., 2009)

4. explore the environmental factors that control genetic diversity and dispersal of riverine fish species (Faulks et al., 2010) and compositional turnover (Turak and Blakey, 2011).

The data have also facilitated the application of systematic conservation planning approaches to riverine systems in Australia (Linke et al., 2011; Turak et al., 2011). In particular, recent enhancements to conservation planning methods to account for catchment connectivity and condition (Linke et al., 2012) depend on the Pfafstetter coding and the broadscale indicators of disturbance provided by the new national framework. Catchment units extracted from this framework also provided planning units for the identification of priority areas for terrestrial biodiversity (Douglass et al., 2011; Klein et al., 2009a, b; Fuller et al., 2010).

A trial of the Australian Government's new high conservation value aquatic ecosystems framework across northern Australia (Kennard, 2010) relied on data supplied by the new stream and nested catchment framework and associated environmental attributes. The DEM stream network delineated riverine hydrosystems (Aquatic Ecosystems Task Group, 2012b) for classification according to the draft Australian National Aquatic Ecosystem Classification Scheme (Aquatic Ecosystems Task Group, 2012a). The ecotopes level of this semi-hierarchical classification scheme was derived by clustering the stream segments according to the similarity of their environmental attributes. The environmental predictors were also used to develop predictive models of the distribution of a wide range of aquatic taxa using sampling units tailored to the ecological characteristics of the faunal group extracted from different levels in the catchment hierarchy. This includes larger catchments (average area $72 \mathrm{~km}^{2}$ ) for modelling the distribution of more mobile taxa such as waterbirds, and finer-resolution catchments (average area $3.5 \mathrm{~km}^{2}$ ) for other aquatic taxa including macroinvertebrates, fish and turtles (Kennard, 2010). The modelled distribution of these 
aquatic taxa, together with the ecotope classification, provided spatially explicit biodiversity surrogates to assess relative conservation value across northern Australia.

The DEM stream network and nested catchments are the foundation data for the Australian Hydrological Geospatial Fabric (the "Geofabric") network streams and catchment products that support the Bureau of Meteorology's water information and accounting needs (http://www.bom. gov.au/water/geofabric/index.shtml). The reporting units for the 2010 Australian Water Resources Assessment (AWRA) (http://www.bom.gov.au/water/about/publications/ document/InfoSheet_10.pdf), the first in a series of annual reports on the availability, quality and use of water to be produced by the bureau, were based on the Level 1 drainage divisions, while the geofabric hydrology reporting regions that will provide finer level catchment delineations for future AWRA assessments are largely delineated by the Level 2 Drainage Basin Groups, except in the MurrayDarling Basin, where the reporting regions are delineated by lower-level Pfafstetter aggregations that represent the AWRC river basins (Australian Government Bureau of Meteorology, 2012). This tailored delineation of the hydrology reporting regions demonstrates the flexibility of the new nested catchment framework and its capacity to be adapted to individual user needs, in this case, the requirement that the reporting regions resemble the AWRC river basins.

\subsection{Limitations and uncertainty}

The new framework consistently represents streams and their catchments at a map scale of about $1: 250000$ and is thus appropriate for applications at regional to continental scale. The environmental attributes are derived from best available, but relatively coarse-scale, national data sources, so are also best suited for applications at regional and national scales.

A primary source of spatial data uncertainty is that associated with the $9 \mathrm{~s}$ DEM representation of height and surface drainage flow paths (Hutchinson et al., 2008). In particular, in areas of dune fields the DEM depicts the land surface underlying the sand ridges and so might more accurately delineate palaeocatchment boundaries (Craddock et al., 2010). The sinks that are the terminal points of the internally draining basins are likely to be reliably identified due to the comprehensive process of verification that was undertaken during the 9 s DEM development (Hutchinson et al., 2008), although the elevation difference between alternate pour points may be small in some cases; thus there is uncertainty as to which neighbouring basin a sink basin would overflow. The variable representation of smaller peaks by the DEM and the reliance on the ANUDEM diagnostics to identify sinks rather than a thorough search (Hutchinson et al., 2008) may also have produced occasional errors in the location of drainage divides and derived terrain attributes. On the other hand, the remarkable consistency of the $9 \mathrm{~s}$ drainage division analysis with that obtained from the earlier $90 \mathrm{~s}$ DEM, derived by Hutchin-
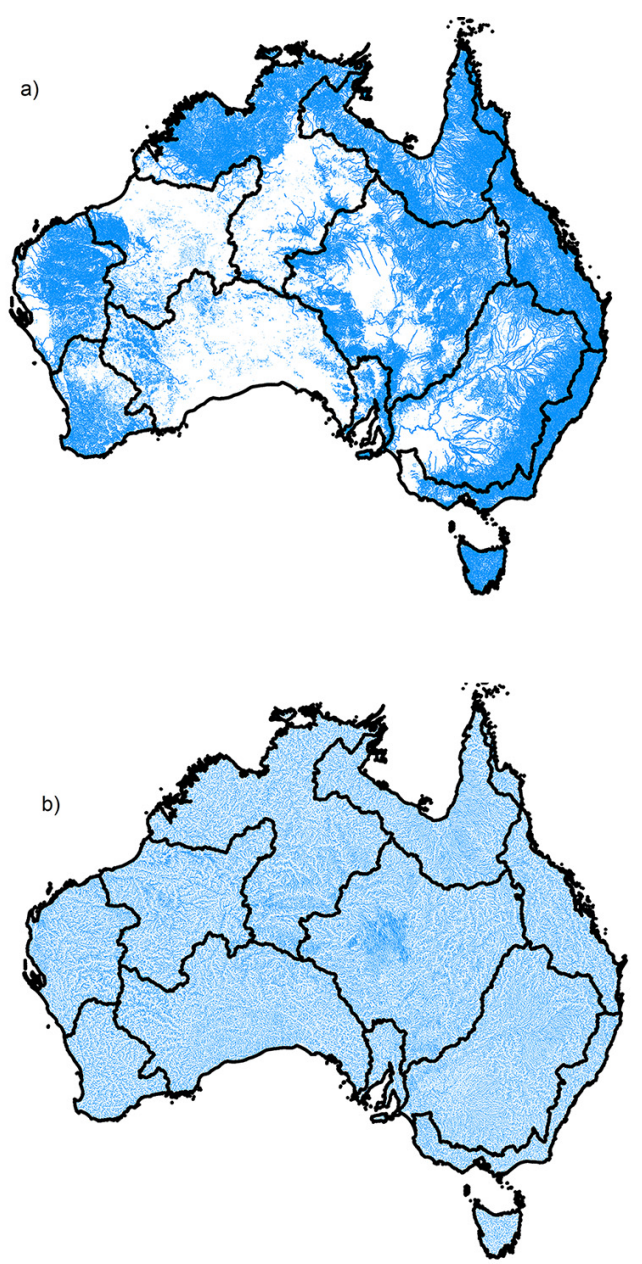

Figure 8. The stream network delineated by (a) this study and (b) that supplied by the HydroSHEDS database. Level 1 drainage divisions are indicated by the bold black lines.

son and Dowling (1991) from completely different source data, indicates broad-scale robustness in the delineation of catchment boundaries from drainage-enforced DEMs.

Floodplains and floodplain flow paths are inadequately represented at the $9 \mathrm{~s}$ DEM resolution. There is no modelling of overbank flow and other floodplain processes and hence the environmental characteristics attributed to isolated floodplain channels (e.g. oxbows, flood runners, etc.) describe the local environment only, not the broader catchment upstream of the associated main river channel. There will also be uncertainty around the location of individual stream links within the more dynamic, braided and anastomosed channel networks though they will be contained within the broaderscale catchment boundaries that contain the floodplain. 
Table 5. A comparison of the new Australian stream and catchment framework with comparable international examples.

\begin{tabular}{llll}
\hline & DEM resolution & $\begin{array}{l}\text { Streamline } \\
\text { mapping scale }\end{array}$ & $\begin{array}{l}\text { Hierarchical } \\
\text { coding system }\end{array}$ \\
\hline Australia & $9 \mathrm{~s}(\sim 270 \mathrm{~m})$ & $1: 250000$ & Pfafstetter \\
USA (McKay et al., 2013; Wang et al., 2011) & $1 / 9$ to $1 \mathrm{~s}(\sim 3$ to $30 \mathrm{~m})$ & $1: 100000$ & $\begin{array}{l}\text { Hydrological Units Code (HUC) } \\
\text { Pfafstetter }\end{array}$ \\
Europe (Vogt et al., 2007) & $100 \mathrm{~m}$ & $1: 100000$ & $1: 50000$ \\
New Zealand (Snelder and Biggs, 2002; & $30 \mathrm{~m}$ & & River Environment Classification* \\
\hline
\end{tabular}

* Supplies a hierarchical context for each stream segment based on its environmental characteristics but not a unique identifier.

a)
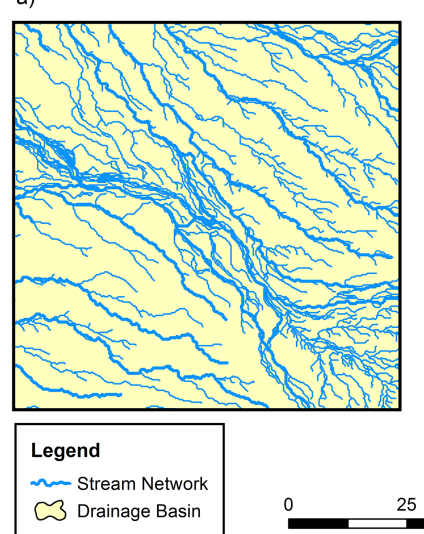

Figure 9. The stream network and drainage basins delineated by (a) this study and (b) supplied by the HydroSHEDS database for the area shown in the inset map of Fig. 4. By recognising distributary drainage connections, one drainage basin is delineated for these rivers draining into the Gulf of Carpentaria, while the HydroSHEDS database delineates multiple basins.

\subsection{International comparisons}

The new national streamline and nested catchment database for Australia, based on the $9 \mathrm{~s}$ DEM, may be compared with catchment frameworks and associated suites of environmental attributes that have been developed to underpin national and global water information needs elsewhere (Table 5). The Australian 9s framework differs in a number of key aspects.

The Australian catchments are based on a coarserresolution DEM and streamline mapping than the comparable international examples. However, unlike the US and European DEMs or that underpinning the HydroSHEDS global database (Lehner et al., 2008), no "stream burning" or other additional hydro-enforcement processes were required to impose stream positions into the DEM. These processes significantly alter the elevation values of the grid cells that comprise the DEM stream network, leading to errors in terrain parameters such as the stream segment slope, catchment relief and terrain curvature that are calculated from the grid cell elevation values. Instead the drainage enforcement applied by the ANUDEM program (Hutchinson, 2011) incorporated the streamlines directly into the elevation gridding (Hutchinson et al., 2008; Hutchinson, 1989). Thus stream positions are accurately located within the DEM without distorting DEM heights. Accordingly, topographic descriptors can be derived directly from the DEM. This includes the large areas of the continent with low topographic relief, effectively overcoming what is commonly seen as a key limitation of DEMs.

The new Australian database overcomes a number of the shortcomings of HydroSHEDS, the best of the global hydrological data sets with Australian coverage, and supplies additional features and attribution. It delineates a finerresolution stream network than the baseline product supplied by HydroSHEDS. Thus, for example, it includes more than 4500 stream segments totalling nearly $10000 \mathrm{~km}$ of stream (mean $2.2 \mathrm{~km}$ ) in the Macleay River basin in northeastern New South Wales, where the 316 HydroSHEDS stream segments total $2176 \mathrm{~km}$ (mean $6.9 \mathrm{~km}$ ). A lowercontributing area threshold can be employed to delineate a finer-resolution stream network from the HydroSHEDS $3 \mathrm{~s}$ flow direction grid. However, this would produce unrealistic patterns of drainage density similar to those of the supplied HydroSHEDS streams (Fig. 8b), delineating streams where surface drainage is absent in arid areas of low relief and highly permeable geology such as the limestone Nullarbor Plain (Australian Bureau of Statistics, 1974). In contrast, the novel methods of drainage analysis described above have reproduced the natural variation in drainage density and the diversity of drainage patterns that are evident at continental scale. Thus, the patterns of drainage density of the derived stream network are graphically indistinguishable from the cartographic streams mapped at a scale of 1:250000 (Fig. 8a). The national framework presented here appears to be the first to derive a stream network from a DEM that explicitly includes complex distributary and anabranching drainage patterns, yet these drainage patterns are common among large rivers globally (Jansen and Nanson, 2004) and occur extensively across the low relief areas of the Australian continent. Thus, for example, our stream network identifies the distributary channels that connect the rivers draining into the Gulf of Carpentaria so that a single drainage basin is delineated (Fig. 4). Like AWRC, however, the HydroSHEDS 
streams do not recognise this connectivity and so delineate a disconnected drainage network and multiple drainage basins for these rivers (Fig. 9).

Our framework also delivers catchments at multiple spatially nested scales and extensive attribution linked to each stream segment and its associated sub-catchment. HydroSHEDS currently supplies just the single, drainage basin scale and minimal attribution. Future HydroSHEDS releases are, however, planned to include additional attribution and nested sub-basin delineations with associated Pfafstetter coding (Lehner and Grill, 2013). We also provide a simple solution to the problem of apportioning accumulated runoff and other attributes between a stream and its anabranch that is appropriate for continental-scale applications.

The coding of the hierarchical relationships between catchments presented here is compatible with that used in the European Catchment Characterization and Modelling data set (CCM). The highest levels in the European catchment hierarchy were formed by grouping basins according to the sea into which they drain and their connectivity to the open ocean (de Jager and Vogt, 2010). This is analogous to our levels 1 and 2 . The CCM similarly applies the Pfafstetter coding scheme to individually code and then internally sub-divide drainage basins. Our application of the Pfafstetter scheme differs, however, in our use of a surrogate for river flow instead of contributing area to distinguish the tributary and main stem, and the necessary inclusion of a method to systematically sub-divide and code the very large number of internally draining basins and distributary stream networks.

\subsection{Data availability and future developments}

The stream and nested catchment database is freely available under a Creative Commons licence - the AHGF version in vector format from http://www.bom.gov.au/water/geofabric/ about.shtml and the original foundation layers in raster format, together with the lookup tables of environmental attributes, from http://ga.gov.au/surfacewater. Future developments include an upgrade of the AHGF foundation layers by Geoscience Australia based on the higher-resolution SRTM $1 \mathrm{~s}$ DEM-S (Gallant et al., 2011) drainage enforced with a compilation of the best available streamline mapping (map scales ranging from $1: 25000$ to $1: 250000$ ). The AHGF upgrade will include tables to link the new stream segments and their catchments to the equivalent features in the 9s DEMderived version so that attribution and other associated data can be easily transferred. There will be fine-scale differences in catchment delineations due to the finer-resolution of the SRTM DEM and the streamline mapping, but also due to the nature of the surface topography depicted by the DEM. Thus the 1s SRTM DEM models the land surface in the year 2000 when the radar observations were collected and so may include anthropogenic features such as large buildings, open cut mines, road cuttings and artificial drainage channels. In contrast, the $9 \mathrm{~s}$ DEM was interpolated from eleva- tion spot heights principally sampled from $1: 100000$ scale contour mapping and essentially represents a pre-European landscape.

\section{Conclusions}

The new stream and nested catchment database supplies a comprehensive spatial framework for regional and national scale planning and assessment across Australia. The structure of this framework reflects the natural hierarchical organisation of the river system and its boundaries respect the surface drainage characteristics of the Australian continent, largely irrespective of administrative or jurisdictional borders. The broad applicability of this framework and its associated environmental database has already been amply demonstrated, suggesting it could provide a useful template to serve the water information needs of other continents.

The successful implementation of the spatial framework across the large areas of low topographic relief and endorheic drainage that make up the majority of the continent has been jointly facilitated by the underpinning drainage-enforced $9 \mathrm{~s}$ DEM and associated drainage analysis methods and a systematic extension of the Pfafstetter system.

Future higher-resolution versions of the catchment framework for Australia will extend its application to management tasks requiring finer-scale information. Nevertheless, the robustness of catchment delineations from drainage-enforced DEMs is likely to generate a high degree of concordance between the $9 \mathrm{~s}$ catchment framework presented here and future finer-scale national catchment frameworks. For many broader-scale planning and assessment tasks the $9 \mathrm{~s}$ framework will still be a suitable choice.

Acknowledgements. We thank the Bureau of Meteorology, Geoscience Australia, the Murray Darling Basin Authority, the Department of the Environment, Water, Heritage and the Arts, and the National Water Commission for funding. This work was also supported by access to the National Computational Infrastructure (NCI) National Facility at the ANU and incorporates data that is ${ }^{\circledR}$ Commonwealth of Australia (Bureau of Meteorology) 2012. We also thank two anonymous reviewers for their helpful suggestions that improved the manuscript.

Edited by: A. Weerts 


\section{References}

Aquatic Ecosystems Task Group: Aquatic Ecosystems Toolkit. Module 2: Interim Australian National Aquatic Ecosystem Classification Framework Australian Government Department of Sustainability, Environment, Water, Population and Communities, Canberra, 2012a.

Aquatic Ecosystems Task Group: Aquatic Ecosystems Toolkit. Module 4: Aquatic Ecosystem Delineation and Description Guidelines, Australian Government Department of Sustainability, Environment, Water, Population and Communities, Canberra, 2012b.

AUSLIG: GEODATA TOPO-250K User Guide, Australian Survey and Land Information Group, Canberra, 1992.

AUSLIG: River Basins of Australia [Digital Dataset], Australian Survey and Land Information Group, 1997.

Australian Bureau of Statistics: Official Year Book of Australia No. 60, 1974, Australian Bureau of Statistics, Canberra, 1974.

Australian Bureau of Statistics: Population Density within 2006 Australian Standard Geographic Classification Census Collector Districts (Compiled by Stephen Wealands, University of Melbourne), Canberra, 2006.

Australian Government Bureau of Meteorology: Australian Hydrological Geospatial Fabric (Geofabric) Data Product Specification. Hydrology Reporting Regions Version 2.1, available at: http://www.bom.gov.au/water/geofabric/documents/v2_1/ ahgf_dps_hydrology_reporting_regions_V2_1_release.pdf (last access: 9 December 2013), 2012.

Australian Government Department of the Environment and Water Resources: Australia - Present Major Vegetation Subgroups - NVIS Stage 1, Version 3.1 - Albers [Digital Dataset], Department of the Environment and Water Resources, Canberra, 2006a.

Australian Government Department of the Environment and Water Resources: Australia - Estimated Pre-1750 Major Vegetation Subgroups - NVIS Stage 1, Version 3.1 - Albers [Digital Dataset], Department of the Environment and Water Resources, Canberra, 2006b.

Australian State of the Environment Committee: Australia State of the Environment 2001, Independent Report to the Commonwealth Minister for the Environment and Heritage, CSIRO Publishing on behalf of the Department of the Environment and Heritage, Canberra, 329 pp., 2001.

Australian Water Resources Council: Review of Australia's Water Resources 1975, Australian Water Resources Council, Australian Government Department of Natural Resources, Canberra, 170 pp., 1976.

Boulton, A. J. and Brock, M. A.: Australian Freshwater Ecology: Processes and Management, Gleneagles Publishing, Adelaide, 300 pp., 1999.

Bureau of Meteorology: Australian Hydrological Geospatial Fabric (Geofabric) Product Guide. Version 1.0, Bureau of Meterology, Canberra, available at: http://www.bom.gov.au/water/geofabric/ index.shtml (last access: 9 December 2013), 2010.

Bureau of Rural Sciences: Integrated Vegetation Cover (2003), Version 1, Department of Agriculture, Fisheries and Forestry, Canberra, 2003.

Bureau of Rural Sciences: Catchment Scale Land Use Mapping for Australia, update April 2009 (CLUM Update 04/09) [Digital Dataset], Bureau of Rural Sciences, Canberra, 2009.
Corkum, L. D.: Conservation of running waters: beyond riparian vegetation and species richness, Aquatic Conserv. Mar. Freshw. Ecosyst., 9, 559-564, 1999.

Craddock, R. A., Hutchinson, M. F., and Stein, J. A.: Topographic data reveal a buried fluvial landscape in the Simpson Desert, Australia, Aust. J. Earth Sci., 57, 141-149, 2010.

Davies, P. E., Harris, J. H., Hillman, T. J., and Walker, K. F.: The Sustainable Rivers Audit: assessing river ecosystem health in the Murray-Darling Basin, Australia, Mar. Freshw. Res., 61, 764777, 2010.

Davies, P. E., Stewardson, M. J., Hillman, T. J., Roberts, J. R., and Thoms, M. C.: Sustainable Rivers Audit 2: The Ecological Health of Rivers in the Murray-Darling Basin at the End of the Millennium Drought (2008-2010), Vol. 1. The Independent Sustainable Rivers Audit Group for the Murray-Darling Basin (ISRAG) Murray Darling Basin Authority, Canberra, MDBA Publication No. 72/12, 2012.

de Jager, A. L. and Vogt, J. V.: Development and demonstration of a structured hydrological feature coding system for Europe, Hydrol. Sci. J., 55, 661-675, 2010.

Döll, P. and Lehner, B.: Validation of a new global 30 min drainage direction map, J. Hydrol., 258, 214-231, 2002.

Douglass, L. L., Possingham, H. P., Carwardine, J., Klein, C. J., Roxburgh, S. H., Russell-Smith, J., and Wilson, K. A.: The effect of carbon credits on savanna land management and priorities for biodiversity conservation, PLoS ONE, 6, e23843, doi:10.1371/journal.pone.0023843, 2011.

Faulks, L. K., Gilligan, D. M., and Beheregaray, L. B.: Islands of water in a sea of dry land: hydrological regime predicts genetic diversity and dispersal in a widespread fish from Australia's arid zone, the golden perch (Macquaria ambigua), Mol. Ecol., 19, 4723-4737, 2010.

Frissell, C. A., Poff, N. L., and Jensen, M. E.: Assessment of biotic patterns in freshwater ecosystems, in: a Guidebook for Integrated Ecological Assessments, edited by: Jensen, M. E. and Bourgeron, P. S., Springer-Verlag, New York, 390-403, 2001.

Fryirs, K. and Brierley, G.: Geomorphic Analysis of River Systems: an Approach to Reading the Landscape, Wiley, Chichester, 2012.

Fuller, R. A., McDonald-Madden, E., Wilson, K. A., Carwardine, J., Grantham, H. S., Watson, J. E. M., Klein, C. J., Green, D. C., and Possingham, H. P.: Replacing underperforming protected areas achieves better conservation outcomes, Nature, 466, 365-367, 2010.

Furby, S.: Remote sensing of land cover change (1970-2000), in: Biomass Estimation: Approaches for Assessment of Stocks and Stock Change. National Carbon Accounting System, Technical Report No. 27, edited by: Richards, G. P., Australian Greenhouse Office, Canberrra, 117-128, 2002.

Gallant, J. C. and Dowling, T. I.: A multi-resolution index of valley bottom flatness for mapping depositional areas, Water Resour. Res., 39, 1347, doi:10.1029/2002WR001426, 2003.

Gallant, J. C., Dowling, T. I., Read, A. M., Wilson, N., Tickle, P., and Inskeep, C.: 1 Second SRTM Derived Digital Elevation Models User Guide, Geoscience Australia, Canberra, 2011.

Garbrecht, J. and Martz, L.: Grid size dependency of parameters extracted from digital elevation models, Comput. Geosci., 20, 8587, 1994. 
Geoscience Australia: Australian Surface Water Management Areas (ASWMA) 2000 Product User Guide, Geoscience Australia, Canberra, 20 pp., 2003a.

Geoscience Australia: GEODATA TOPO 250K Series 2 Topographic Data, Geoscience Australia, Canberra, 2003b.

Geoscience Australia: GEODATA TOPO 250K Series 3 Topographic Data, Geoscience Australia, Canberra, 2006.

Gilligan, D.: The condition of freshwater fish assemblages in the Bellinger Catchment, NSW. A report to the Northern Rivers Catchment Management Authority NSW Department of Industry \& Investment Batemans Bay, New South Wales, Australia, available at: http://www.dpi.nsw.gov.au/_data/ assets/pdf_file/0004/400495/AE_2011_Output-1805_Gilligan_ Bellingen-Ecohealth-Report_REPORT.pdf (last access: 9 December 2013), 2010.

Hammer, U. T.: Saline Lake Ecosystems of the World, Volume 59 of Monographiae Biologicae, Dr. W. Junk, Dordrecht, 1986.

Hughes, R. M., Paulsen, S. G., and Stoddard, J. L.: EMAP-Surface Waters: a multiassemblage, probability survey of ecological integrity in the USA, Hydrobiologia, 422, 429-443, 2000.

Hutchinson, M. F.: A new method for gridding elevation and streamline data with automatic removal of pits, J. Hydrol., 106, 211-232, 1989.

Hutchinson, M. F.: ANUSPLIN Version 4.3. Fenner School of Environment and Society, Australian National University, Australia, available at: http://fennerschool.anu.edu.au/research/ products (last access: 10 December, 2013), 2004.

Hutchinson, M. F.: ANUDEM Version 5.3 User Guide. Fenner School of Environment and Society, Australian National University, Canberra, available at: http://fennerschool.anu.edu.au/ research/products (last access: 9 December, 2013), 2011.

Hutchinson, M. F. and Dowling, T. I.: A continental hydrological assessment of a new grid-based digital elevation model of Australia, Hydrol. Process., 5, 31-44, 1991.

Hutchinson, M. F., Stein, J. L., and Stein, J. A.: Nested Catchments and Sub-Catchments for the Australian Continent [Digital Dataset], available at: http://adl.brs.gov.au/anrdl/metadata_files/ pa_ancs_r9gm_00211a01.xml (last access: 9 December 2013), 2000.

Hutchinson, M. F., Nix, H. A., and McTaggart, C.: GROWEST Version 2.0. Fenner School of Environment and Society, Australian National University, Australia, available at: http://fennerschool. anu.edu.au/research/products (last access: 9 December 2013), 2004.

Hutchinson, M. F., Stein, J. A., Stein, J. L., Anderson, H., and Tickle, P.: GEODATA 9 Second DEM and D8. Digital Elevation Model Version 3 and Flow Direction Grid User Guide: available at: https://www.ga.gov.au/image_cache/GA11644.pdf (last access: 10 December 2013), 2008.

Jansen, J. D. and Nanson, G. C.: Anabranching and maximum flow efficiency in Magela Creek, northern Australia, Water Resour. Res., 40, W04503, doi:10.1029/2003wr002408, 2004.

Jensen, M. E., Christensen, N. L. J., and Bourgeron, P. S.: An overview of ecological assessment principles and applications, in: A Guidebook for Integrated Ecological Assessments, edited by: Jensen, M. E. and Bourgeron, P. S., Springer-Verlag, New York, 13-28, 2001.
Jenson, S. K.: Applications of hydrologic information automatically extracted from digital elevation models, Hydrol. Process., 5, 3144, 1991

Jerie, K., Household, I., and Peters, D.: Tasmania's river geomorphology: stream character and regional analysis, Volume 1, Nature Conservation Branch, Department of Primary Industries, Water and Environment, Nature Conservation Report 03/5, 126 pp., Hobart, 2003.

Kennard, M. J. (Ed.).: Identifying high conservation value aquatic ecosystems in northern Australia. Final Report for the Department of Environment, Water, Heritage and the Arts and the National Water Commission, available at: http://www.environment.gov.au/water/publications/ policy-programs/nawfa-hcvae-trial-report.html (last access: 9 December 2013), 2010.

Kesteven, J., Landsberg, J., and URS Australia: Developing a national forest productivity model, Australian Greenhouse Office, Canberra, National Carbon Accounting System Technical Report, 104 pp., 2004.

Kingsford, R. T., Boulton, A. J., and Puckridge, J. T.: Challenges in managing dryland rivers crossing political boundaries: lessons from Cooper Creek and the Paroo River, central Australia, Aquatic Conserv. Mar. Freshw. Ecosyst., 8, 361-378, 1998.

Kingsford, R. T., Thomas, R. F., and Curtin, A. L.: Conservation of wetlands in the Paroo and Warrego catchments in arid Australia, Pacific Conserv. Biol., 7, 21-33, 2001.

Kingsford, R. T., Dunn, H., Love, D., Nevill, J., Stein, J. L., and Tait, J. T.: Protecting Australia's rivers, wetlands and estuaries of high conservation value, Department of Environment and Heritage Australia, available at: http://www.environment.gov.au/ water/publications/environmental/protecting-rivers.html (last access: 9 December 2013), 2005.

Klein, C., Wilson, K., Watts, M., Stein, J., Berry, S., Carwardine, J., Stafford Smith, M., Mackey, B., and Possingham, H.: Incorporating ecological and evolutionary processes into large-scale conservation planning, Ecol. Appl., 19, 206-217, 2009a.

Klein, C. J., Wilson, K. A., Watts, M., Stein, J., Carwardine, J., Mackey, B., and Possingham, H. P.: Spatial conservation prioritization inclusive of wilderness quality: a case study of Australia's biodiversity, Biol. Conserv., 142, 1282-1290, 2009b.

Lehner, B., and Grill, G.: Global river hydrography and network routing: baseline data and new approaches to study the world's large river systems, Hydrol. Process., 27, 2171-2186, doi:10.1002/hyp.9740, 2013.

Lehner, B., Verdin, K., and Jarvis, A.: New global hydrography derived from spaceborne elevation data, EOS Trans. Am. Geophys. Union, 89, 93-94, 2008.

Linke, S., Turak, E., and Nel, J.: Freshwater conservation planning: the case for systematic approaches, Freshw. Biol., 56, 6-20, 2011.

Linke, S., Kennard, M. J., Hermoso, V., Olden, J. D., Stein, J., and Pusey, B. J.: Merging connectivity rules and large-scale condition assessment improves conservation adequacy in river systems, J. Appl. Ecol., 49, 1036-1045, 2012.

Liu, S. F., Raymond, O. L., Stewart, A. J., Sweet, I. P., Duggan, M., Charlick, C., Phillips, D., and Retter, A. J.: Surface geology of Australia 1:1000 000 scale, Northern Territory [Digital Dataset], The Commonwealth of Australia, Geoscience Australia, Canberra, 2006. 
McKay, L., Bondelid, T., Dewald, T., Rea, A., Johnston, C., and Moore, R.: NHDPlus Version 2: User Guide (Data Model Version 2.1), United States Environmental Protection Agency, 2013.

McMahon, T. A., Vogel, R. M., Peel, M. C., and Pegram, G. G. S.: Global streamflows - Part 1: Characteristics of annual streamflows, J. Hydrol., 347, 243-259, 2007.

Montgomery, D. R. and Foufoula-Georgiou, E.: Channel network source representation using digital elevation models, Water Resour. Res., 29, 3925-3934, 1993.

National Land and Water Resources Audit: Rainfall erosivity (R factor) [Digital Dataset], available at: http://data.daff.gov.au/ anrdl/metadata_files/pa_rer_r9cl__00511a00.xml (last access: 10 December 2013), 2000.

Ormerod, S. J.: Three challenges for the science of river conservation, Aquatic Conserv. Mar. Freshw. Ecosyst., 9, 551-558, 1999.

Pusey, B. J., Kennard, M. J., Stein, J. L., Olden, J. D., Mackay, S. J., Hutchinson, M. F., and Sheldon, F.: Ecohydrological Regionalisation of Australia: a tool for management and science. Innovations Project GRU36, Final Report to Land and Water Australia, Land and Water Australia, Canberra, available at: http: //lwa.gov.au/products/pn22591 (last access: 10 December 2013), 2009.

Raupach, M. R., Kirby, J. M., Barrett, D. J., and Briggs, P. R.: Balances of Water, Carbon, Nitrogen and Phosphorus in Australian Landscapes: (1) Project Description and Results, CSIRO Land and Water, Technical Report 40/01, Canberra, 2001.

Raupach, M. R., Briggs, P. R., Haverd, V., King, E. A., Paget, M., and Trudinger, C. M.: Australian Water Availability Project (AWAP): CSIRO Marine and Atmospheric Research Component: Final Report for Phase 3, CAWCR Technical Report No. 013. 67 pp., 2009

Raupach, M. R., Briggs, P. R., Haverd, V., King, E. A., Paget, M., and Trudinger, C. M.: Australian Water Availability Project, CSIRO Marine and Atmospheric Research, available at: http: //www.csiro.au/awap (last access: 25 March 2014), 2012.

Raymond, O. L., Liu, S. F., and Kilgour, P.: Surface geology of Australia 1: 1000000 scale, Tasmania, 3rd Edn. [Digital Dataset], The Commonwealth of Australia, Geoscience Australia, Canberra, 2007a.

Raymond, O. L., Liu, S. F., Kilgour, P., Retter, A. J., and Connolly, D. P.: Surface geology of Australia $1: 1000000$ scale, Victoria, 3rd Edn. [Digital Dataset], The Commonwealth of Australia, Geoscience Australia, Canberra, 2007b.

Raymond, O. L., Liu, S. F., Kilgour, P. L., Retter, A. J., Stewart, A. J., and Stewart, G.: Surface geology of Australia 1 : 1000000 scale, New South Wales, 2nd Edn. [Digital Dataset], The Commonwealth of Australia, Geoscience Australia, Canberra, 2007c.

Renssen, H. and Knoop, J. M.: A global river routing network for use in hydrological modeling, J. Hydrol., 230, 230-243, 2000.

Snelder, T. H. and Biggs, B. J. F.: Multi-scale river environment classification for water resource management, J. Am. Water Resour. Assoc., 38, 1225-1239, 2002.

Stein, J. L.: A continental landscape framework for systematic conservation planning for Australian rivers and streams, $\mathrm{Ph}$. D. thesis, Centre for Resource and Environmental Studies, Australian National University, Canberra, available at: http://hdl.handle.net/ 1885/49406 (last access: 10 December 2013), 2006.
Stein, J. L. and Hutchinson, M. F.: A review of nested catchment reference systems for Version 1.0 of the National Catchments and Reporting Units, Report to the Bureau of Meteorology, Fenner School of Environment and Society, Australian National University, Canberra, 25 pp., 2008.

Stein, J. L., Stein, J. A., and Nix, H. A.: The Identification of Wild Rivers, Methodology and Database Development, Environment Australia, Canberra, 73 pp., available at: http://www.environment.gov.au/heritage/publications/ anlr/wild-river-identification.html (last access: 10 December 2013), 1998.

Stein, J. L., Stein, J. A., and Nix, H. A.: Spatial analysis of anthropogenic river disturbance at regional and continental scales: identifying the wild rivers of Australia, Landsc. Urban Plan., 60, $1-25,2002$.

Stein, J. L., Hutchinson, M. F., and Stein, J. A.: Appendix 7. Development of a continent-wide spatial framework, in: Ecohydrological regionalisation of Australia: a tool for management and science. Innovations Project GRU36, Final Report to Land and Water Australia, edited by: Pusey, B. J., Kennard, M. J., Stein, J. L., Olden, J. D., Mackay, S. J., Hutchinson, M. F., and Sheldon, F., Land and Water Australia, Canberra, 1-13, available at: http://lwa.gov.au/products/pn22591 (last access: 10 December 2013), 2009a.

Stein, J. L., Hutchinson, M. F., Pusey, B. J., and Kennard, M. J.: Appendix 8. Ecohydrological classification based on landscape and climate data, in: Ecohydrological Regionalisation of Australia: a Tool for Management and Science. Innovations Project GRU36, Final Report to Land and Water Australia, edited by: Pusey, B. J., Kennard, M. J., Stein, J. L., Olden, J. D., Mackay, S. J., Hutchinson, M. F., and Sheldon, F., Land and Water Australia, Canberra, 1-48, available at: http://lwa.gov.au/ products/pn22591 (last access: 10 December 2013), 2009 b.

Stewart, A. J., Sweet, I. P., Needham, R. S., Raymond, O. L., Whitaker, A. J., Liu, S. F., Phillips, D., Retter, A. J., Connolly, D. P., and Stewart, G.: Surface geology of Australia 1 : 1000000 scale, Western Australia [Digital Dataset], The Commonwealth of Australia, Geoscience Australia, Canberra, 2008.

Turak, E. and Blakey, R.: Using compositional turnover for observing changes in freshwater biodiversity at broad-spatial scales (abstract), ASL \& NZFSS 2011 Congress, "Variability and the future of aquatic ecosystems in Australia and New Zealand", Brisbane, Queensland, 2011.

Turak, E., Ferrier, S., Barrett, T., Mesley, E., Drielsma, M., Manion, G., Doyle, G., Stein, J., and Gordon, G.: Planning for the persistence of river biodiversity: exploring alternative futures using process-based models, Freshw. Biol., 56, 39-56, 2011.

US Geological Survey: HYDRO1K Elevation Derivative Database, available at: https://lta.cr.usgs.gov/HYDRO1K (last access: 18 October 2013), 2001.

van de Graaff, W. J. E., Crowe, R. W. A., Bunting, J. A., and Jackson, M. J.: Relict early Cainozoic drainages in arid Western Australia, Z. Geomorphol., 21, 379-400, 1977.

Veitch, S. M. and Walker, J.: Continental Scale Data - an Under-Valued Resource for Environmental Indicator and MultiCriterion Natural Resource Assessments, ISESS 2001, Banff, Canada, 2001, 
Verdin, K. L. and Verdin, J. P.: A topological system for delineation and codification of the Earth's river basins, J. Hydrol., 218, 1-12, 1999.

Vörösmarty, C. J., Fekete, B. M., Meybeck, M., and Lammers, R. B.: Geomorphic attributes of the global system of rivers at 30 min spatial resolution, J. Hydrol., 237, 17-39, 2000.

Vogt, J., Soille, P., de Jager, A., Rimaviciute, E., Mehl, W., Foisneau, S., Bódis, K., Dusart, J., Paracchini, M. L., Haastrup, P., and Bamps, C.: A pan-European River and Catchment Database, European Commission, Joint Research Center, Institute for Environment and Sustainability, Ispra, Italy, JRC 40291, 124 pp., 2007.

Walsh, C., Stewardson, M., Stein, J., and Wealands, S.: Sustainable Rivers Audit Filters Project Stage 2. Report to Murray Darling Basin Commission, University of Melbourne, Melbourne, 54 pp., 2007.

Wang, L., Infante, D., Esselman, P., Cooper, A., Wu, D., Taylor, W., Beard, D., Whelan, G., and Ostroff, A.: A hierarchical spatial framework and database for the national river fish habitat condition assessment, Fisheries, 36, 436-449, 2011.

Western, A. and McKenzie, N.: Soil hydrological properties of Australia, Version 1.0.1 [Digital Dataset], CRC for Catchment Hydrology, Melbourne, 2004.
Whitaker, A. J., Champion, D. C., Sweet, I. P., Kilgour, P., and Connolly, D. P.: Surface geology of Australia 1: 1000000 scale, Queensland, 2nd Edn. [Digital Dataset], The Commonwealth of Australia, Geoscience Australia, Canberra, 2007.

Whitaker, A. J., Glanville, D. H., English, P. M., Stewart, A. J., Retter, A. J., Connolly, D. P., Stewart, G. A., and Fisher, C. L.: Surface geology of Australia 1: 1000000 scale, South Australia [Digital Dataset], The Commonwealth of Australia, Geoscience Australia, Canberra, 2008.

Wild, M., Snelder, T., Leathwick, J., Shankar, U., and Hurren, H.: Environmental variables for the Freshwater Environments of New Zealand River Classification, National Institute of Water and Atmosperic Research, Christchurch, New Zealand, NIWA Client Report, 31, 2005.

Wilson, P. and Nason, S.: SACRED Stream and Catchment References for Environmental Data. A Stream Numbering System for Victoria, Waterways and Salinity Section, Natural Resources System Division, Department of Conservation and Environment, 1991.

$\mathrm{Xu}, \mathrm{T}$. and Hutchinson, M. F.: New developments and applications in the ANUCLIM spatial climatic and bioclimatic modelling package, Environ. Modell. Softw., 40, 267-279, 2013. 